\title{
Konsep Kerja Sama Bagi Hasil Kelapa Sawit di Kecamatan Dayun Kabupaten Siak Provinsi Riau (Tinjauan Fiqih Muamalah)
}

\author{
Oktarijayanti ${ }^{1}$ Daharmi Astuti ${ }^{2}$ Boy Syamsul Bakhri ${ }^{3 *}$ \\ * 1,2 \&3Fakultas Agama Islam Universias Islam Riau (UIR) Pekanbaru \\ Jl. Kaharuddin Nasution No. 113 Perhentian Marpoyan Pekanbaru 28284 \\ e-mail : daharmi_astuti@fis.uir.ac.id; bsb_fai@fis.uir.ac.id
}

\begin{abstract}
Abstrak: Kerjasama bagi hasil merupakan salah satu model transaksi ekonomi untuk mendapatkan keuntungan (Mudharabah) antara kedua belah pihak, pemilik lahan dan pengelola, terutama dalam akad perkebunan sawit. Persoalan yang dikaji bagaimana sistem kerjasama bagi hasil kelapa sawit di Desa Dayun Kabupaten Siak. Tujuan penelitian untuk mengetahui konsep dan pelaksanaan bagi hasil kelapa sawit menurut Fiqih Muamalah. Jenis penelitian adalah penelitian lapangan (Field Research). Untuk mendapatkan data yang valid peneliti menggunakan sumber data primer dan data sekunder. Metode pengumpulan data dokumentasi, wawancara dan dianalisis dengan metode kualitatif. Hasil penelitian menunjukkan bahwa konsep bagi hasil masyarakat Desa Dayun Kecamatan Dayun adalah syirkah mudharabah dimana pemilik menyediakan lahan dan peralatan untuk perkebunan kelapa sawit sedangkan pengelola menyediakan waktu, tenaga untuk mengelola kebun tersebut. Sistem bagi hasil yang dilakukan : Pertama, $\frac{1}{5}$ dari hasil panen untuk pengelola atau pekerja dan $\frac{4}{5}$ untuk pemilik kebun dengan catatan peralatan dan kerusakan alat ditanggung oleh pemilik kebun. Kedua, separoh dari hasil panen untuk pengelola atau pekerja dan separuh lagi untuk pemilik kebun atau lahan dengan catatan peralatan dan kerusakan Alat ditanggung oleh pengelola. Dilihat dari aspek hukum Islam tetap sah karena ada akad saat melakukan perjanjian, meskipun tidak secara tertulis. Kerjasama bagi hasil ini juga memiliki kelemahan, dikarenakan ada beberapa faktor yang mempengaruhinya di antaranya tidak adanya ikatan perjanjian tertulis. Ke depan harus ada perjanjian tertulis agar memberi jaminan hukum bagi kedua belah pihak.
\end{abstract}

Kata Kunci: Kerjasama Bagi Hasil, Syirkah Mudharabah, Fiqih Muamalah 


\section{PENDAHULUAN}

Manusia dijadikan Allah SWT sebagai makhluk sosial yang saling menguntungkan antara satu dengan yang lainnya, untuk memenuhi kebutuhan hidupnya, manusia harus berusaha mencari karunia Allah SWT yang ada di muka bumi ini sebagai sumber ekonomi. Cara yang ditempuh dalam mencari karunia itu adalah dengan usaha dan bekerja sama dengan manusia lainnya. Tetapi dalam usaha dan kerja sama tersebut hendaklah didasari dengan akad atau perjanjian yang telah disepakati bersama.

Salah satu hasil karunia dari Allah SWT adalah adanya tanaman kelapa sawit yang dapat dimanfaatkan oleh manusia untuk menunjang kebutuhan hidup sehari hari. Tanaman kelapa sawit merupakan salah satu jenis tanaman perkebunan yang menduduki posisi penting dalam sektor pertanian umumnya, dan sektor perkebunan khususnya. Hal ini disebabkan karena dari sekian banyak tanaman yang menghasilkan minyak atau lemak, kelapa sawit yang menghasilkan nilai ekonomi terbesar per hektar di dunia. Kelapa sawit merupakan komoditi andalan Indonesia yang perkembangannya demikian pesat.

Siak salah satu Kabupaten terbesar yang memiliki wilayah Kecamatan dan memiliki lahan yang sangat luas yang terbagi dari beberapa Desa. Siak merupakan Kabupaten yang banyak melakukan perjanjian sistem bagi hasil,ini dikarenakan sebagian besar penduduk hidup dengan mata pencarian bertani. Hal ini berarti bahwa sebagian besar rakyat menggantungkan hidupnya dari sektor pertanian. Sebagai wilayah yang agraris masyarakat berusaha dalam memantapkan pembangunan di bidang perkebunan. Salah satu kecamatan yang ada di Kabupaten Siak adalah Kecamatan Dayun. Kecamatan Dayun merupakan salah satu sektor penghasil kelapa sawit yang cukup mendominasi di Kabupaten Siak. Umumnya masyarakat yang tinggal di Kecamatan Dayun memiliki kebun kelapa sawit. Masyarakat Desa yang ada berawal dari penduduk yang ada di daerah Jawa yang mengikuti program transmigrasi.

Di kecamatan Dayun terdiri dari 11 Desa di antaranya adalah ada Desa Banjar Seminai, Desa Berumbung Baru, Desa Buana Makmur, Desa Dayun, Desa Lubuk Tilan, Desa Merangkai, Pangkalan Makmur, Sawit Permai, Sialang Sakti, Suka Mulya dan Desa Taluk Merbau (Indonesia.go.id) yang mana dari tiga Desa memiliki lahan luas kelapa sawit di antaranya Desa Taluk Merbau, Desa Dayun Desa Suka Mulya Desa yang terdapat di Kecamatan Dayun Kabupaten Siak yang memiliki wilayah perkebunan yang luas yang berpotensi bagi pengembangan agro industri dan agrowisata khususnya pengolahan CPO (Crude Palm Oil) atau minyak kelapa sawit. Mayoritas penduduk menjadi petani yang memiliki kebun sawit, menjadikan perkebunan sawit menjadi suatu usaha pokok yang dapat memenuhi kebutuhan primer dan sekunder mereka. Hanya saja tidak semua penduduk di sini mempunyai lahan ataupun kebun sawit. Sehingga mereka harus bekerjasama dengan orang yang memiliki perkebunan kelapa sawit.

Bentuk kerja sama yang dilakukan oleh kedua belah pihak ini ada dua macam yaitu sistem upah yang dibayarkan pemilik kebun sawit kepada pemanen dan sistem bagi hasil. Untuk sistem upah, pemilik kebun membayarkan upah pemanen sesuai dengan yang telah disepakati oleh kedua belah pihak dan berlaku hanya untuk sekali panen. Pemilik kebun saat akan melakukan panen menyepakati biaya upah yang akan dibayar kepada pemanen atau penggarap sesuai dengan kesepakatan. Sedangkan bagi hasil akan dibagi sesuai dengan kesepakatan kedua belah pihak. dengan demikian dalam melakukan hubungan 
kerjasama dapat menimbulkan suatu persoalan hukum mengenai hak dan kewajiban. Adapun hak dan kewajiban bagi pemilik kebun antara lain :

Sedangkan hak bagi pemilik lahan.

1. Pemilik menyediakan alat-alat seperti : dodos, egrek, gerobak, gancu dan lain lain

2. Sedangkan hak bagi pemilik kebun adalah menerima hasil dari garapannya.

Sedangkan kewajiban bagi penggarap antara lain :

1. Melakukan penggarapan secara baik sesuai dengan ketentuan yang telah disepakati bersama dan menghindari kecerobohan dalam melakukan penyadap yang menyebabkan kerusakan atau kematian.

2. Memberikan hasil garapan kepada pemilik sesuai dengan kesepakatan.

Berdasarkan hasil pengamatan awal, penulis menemukan beberapa fenomena yang berkaitan dengan sistem bagi hasil yaitu :

1. Kurangnya transparasi keuntungan lahan oleh pemilik lahan dan pengelola/ pengarap.

2. Pemilik lahan selalu bebas untuk memberhentikan atau memutuskan hubungan kerja sama dengan pengelola / penggarap kebun sawit.

3. Kesepakatan yang terjadi antara kedua belah pihak (pemilik lahan dan penggarap) hanya didasarkan rasa kepercayaan kesepakatan secara lisan.

4. Pengelola merasa dirugikan dengan sistem bagi hasil karena tidak sesuai dengan tenaga yang telah dikeluarkan.

Dari uraian yang dikemukakan di atas, jelas terlihat perjanjian bagi hasil ini bertentangan dengan ketentuan hukum Islam. Bahkan Nabi Muhammad SAW dan begitu pula para sahabat pernah mengadakan perjanjian bagi hasil dalam bidang pertanian.

Bagi hasil tanah perkebunan dalam Islam sebagaimana dibahas dalam kitabkitab fiqih, pengelolaannya dilakukan dengan beberapa macam cara yang dikenal dengan istilah muzara'ah, mudharabah, musaqah dan musyarakah. Itu merupakan sebagian bentuk dari aqad atau transaksi muamalah Islam dalam bidang pemanfaatan tanah. Atas dasar keterangan di atas, maka kerja sama dengan sistem bagi hasil diakui keberadaannya dalam agama Islam dan bila dapat dilaksanakan dengan ketentuannya tentu akan dapat membantu pihak yang melaksanakannya.

Pembagian hasil produksi juga merupakan salah satu langkah yang inovatif dalam transaksi ekonomi Syariah, hal tersebut dapat terjadi apabila kesepakatan kerjasama sesuai dengan prilaku masyarakat, lebih dari itu kesepakatan pembagian hasil produksi merupakan langkah keseimbangan sosial antara kedua belah pihak dalam memperoleh kesempatan untuk melakukan kegiatan usaha yang produktif. Pelaksanaan bagi hasil yang dilakukan oleh masyarakat di Kecamatan Dayun Kabupaten Siak biasanya pengelola hanya mendapatkan bagian $\frac{1}{5}$ dari hasil panen kelapa sawit dan pemilik mendapatkan $\frac{4}{5}$ dari hasil panen kelapa sawit dengan catatan resiko kerusakan di tangan pemilik lahan. Maka dari itu penelitian ini perlu dikaji bagaimana konsep bagi hasil pelaksanaan kerjasama bagi hasil kelapa sawit di Kecamatan Dayun Kabupaten Siak Provinsi Riau tinjauan Fiqih Muamalah

\section{TINJAUAN PUSTAKA Bagi Hasil}

Menurut istilah bahasa Arab bagi hasil (mudharabah) ikut bentuk mufaa'ala yang berasal dari kata adh-dharb fi al ardh 
artinya berjalan di bumi untuk menghasilkan uang. Disebut juga dengan qiradh dengan huruf qaf berharkat kasrah dan huruf $r a^{\prime}$ berharkat fathah tanpa tasydid yang berasal dari kata qardh yang artinya memutuskan atau memotong (Abdurahman, 2006:21).

Bagi hasil adalah perjanjian atau ikatan bersama di dalam melakukan kegiatan usaha. Di dalam usaha tersebut diperjanjikan adanya pembagian hasil atas keuntungan yang akan didapat antara kedua belah pihak atau lebih. Bagi hasil merupakan suatu langkah inovatif dalam Ekonomi Islam yang tidak hanya sesuai dengan perilaku masyarakat, namun lebih dari itu bagi hasil merupakan suatu langkah keseimbangan sosial dalam memperoleh kesempatan ekonomi. Bagi hasil dapat dipandang sebagai langkah yang lebih efektif untuk mencegah terjadinya konflik kesenjangan antara si kaya dan si miskin dalam kehidupan bermasyarakat.

\section{Prinsip Bagi Hasil}

Prinsip bagi hasil (Profit Sharing) merupakan karakteristik umum dan landasan bagi operasional bank Islam secara keseluruhan. Prinsip bagi hasil dalam simpanan/tabungan tersebut menetapkan

tingkat keuntungan/pendapatan bagi tiap-tiap pihak. Pembagian keuntungan dilakukan melalui tingkat perbandingan rasio, bukan ditetapkan dalam jumlah yang pasti (Hakim 2012: 105).

Qiradh adalah pemberian dana oleh seseorang kepada orang lain untuk diolah dengan cara berniaga, di mana keuntungan yang diperoleh dibagi antara keduanya dengan syarat-syarat yang telah ditentukan oleh mereka. Sedangkan Mudharabah adalah akad kerjasama antara dua orang dimana yang satu memberikan sejumlah uang sedangkan yang lain memberikan jasa tenaga untuk mengolah uang tersebut. Keuntungan yang dihasilkan dari usaha ini dibagi dua berdasarkan syarat yang telah mereka tentukan.

Untuk lebih rinci mengenai prinsipprinsip bagi hasil usaha Islam dapat diuraikan sebagai berikut.

Tauhid, yang secara harfiah berarti satu atau esa, dalam konteks ekonomi menganjurkan seseorang bagaimana berhubungan dengan orang lain dalam hubungannya dengan tuhannya. Prinsip ini menyatakan dibelakang praktek ekonomi didasarkan atas pertukaran, alokasi sumber daya, kepuasan dan keuntungan, dan ada satu keyakinan yang sangat fundamental, yakni keadilan sosial.

Prinsip Kerja, Prinsip ini menegaskan tentang kerja dan kompensasi dari kerja yang telah dilakukan. Prinsip ini juga menentukan bahwa seseorang harus profesional dengan kategori pekerjaan yang dikerjakan. Yaitu harus ada perhitungan misalnya "jam orang kerja" dan harus pula kategori yang spesifik bagi setiap pekerja atau keahlian. Kemudian upah dari setiap spesifikasi itu harus pula didasarkan atas upah minimum dan disesuaikan dengan hukum pemerintahan.

Prinsip Distribusi dan Kekayaan, Di sini ditegaskan adanya hak masyarakat untuk mendistribusikan kekayaannya yang digunakan untuk tujuan redistribusi dalam sebuah sistem ekonomi Islam adalah zakat, shadaqah, ghamimah. Hukum Islam tentang warisan mendorong untuk mendistribusikan kekayaan seseorang. Jadi redistribusi pendapatan dan kekayaan secara merata berlaku terhadap Negara dan dasar ketauhidan dan persaudaraan. Tujuannya adalah untuk meningkatkan transformasi yang produktif dari pendapatan dan kekayaan nasional menjadi kesempatan kerja untuk mewujudkan kesejahteraan bagi warga Negara.

Prinsip Keseimbangan, merupakan nilai dasar yang bisa berpengaruh terhadap berbagai aspek kehidupan ekonomi Islam 
misalnya kesederhanaan, berhemat dan menjauhi pemborosan. Konsep keseimbangan ini tidak hanya perbandingan perbaikan hasil usaha yang diarahkan untuk dunia dan akhirat saja, akan tetapi juga berkaitan dengan kepentingan umum yang harus dipelihara dan keseimbangan antara hak dan kewajiban.

\section{Konsep Bagi Hasil}

Konsep bagi hasil ini sangat berbeda dengan bunga yang diterapkan oleh sistem ekonomi konvensional. Dalam ekonomi syariah konsep bagi hasil dapat dijabarkan sebagai berikut:

1. Pemilik dana menanamkan dananya melalui institusi keuangan yang bertindak sebgai pengelola dana.

2. Pengelola mengelola dana-dana tersebut dalam sistem yang dikenal dengan system pool of find (penghimpun dana), selanjutnya pengelola akan menginvestasikan dana-dana tersebut kedalam proyek atau usaha-usaha yang layak dan menguntungkan serta memenuhi semua aspek syariah.

3. Kedua belah pihak membuat kesepakatan (Akad) yang berisi ruang lingkup kerja sama, jumlah nominal dana, dan jangka waktu berlakunya kesepakatan tersebut.

4. Sumber dana terdiri dari :

a. Simpanan : tabungan dan simpanan berjangka

b. Modal : simpanan poko, simpanan wajib, dan lain-lain.

Hutang pihak lain.

\section{METODE PENELITIAN}

Jenis penelitian yaitu penelitian lapangan (Field Research) dengan menggunakan metode penelitian kualitatif. Penelitian kualitatif adalah sebuah pendekatan fenomena yaitu mengamati dan meneliti masalah atau keadaan tertentu yang menjadi objek penelitian (Sonny Leksono 2013:181) suatu proses penelitian dan pemahaman yang berdasarkan pada metodologi yang menyelidiki suatu fenomena sosial dan masalah manusia. Pada pendekatan ini peneliti menekankan sifat realitas yang terbangun secara sosial, hubungan erat antara peneliti dan subjek yang diteliti. Selain itu penelitian ini termasuk penelitian deskriptif kualitatif yaitu penelitian yang dimaksudkan untuk menyelidiki keadaan, kondisi atau hal lainlain yang sudah disebutkan, yang hasilnya dipaparkan dalam bentuk laporan penelitian (Arikunto, 2010:3).

Populasi masyarakat Desa Dayun sekitar 4.964 orang. Dari desa ini, yang memiliki lahan sawit atau petani sawit terbagi menjadi 37 kelompok tani perdesa. Jumlah petani yang memiliki lahan kelapa sawit adalah 659 kepala keluarga di desa dayun, Dengan jumlah lahan kelapa sawit keseluruhan adalah +/- 300 Ha. Sampel dalam penelitian ini adalah 30 pemilik lahan sawit dan pengelola lahan sawit yaitu 5 pemilik dan 5 pengelola di desa Dayun dengan menggunakan metode purposive sampling.

Analisis data dalam penelitian ini menggunakan analisis deskriptis kualitatif adalah proses mencari dan menyususn secara sistematis data yang telah diperoleh dari wawancara, catatan lapangan dan bahan-bahan lain sehingga mudah untuk dipahami dan temuanya dapat diinformasikan kepada fokus penelitian (Sugiyono, 2009: 244).

Teknis analisis data yaitu data penelitian ini diolah dari hasil wawancara, dokumentasi dan kepustakaan dengan menggunakan analisis deskriptif kualitatif, yakni penulis mencoba memaparkan semua data dan informasi yang diperoleh kemudian menganalisa data dengan berpedoman dengan sumber-sumber tertulis. 
Data yang telah terkumpul tersebut dianalisis secara deskriptif kualitatif yang menguraikan pelaksanaan bagi hasil kelapa sawit dari sudut pandang fiqih muamalah. selanjutnya pengembalian kesimpulan menguraikan tentang pelaksanaan bagi hasil pengelolaan lahan kelapa sawit perspektif fiqih muamalah sebagai jawaban permasalahan yang telah dirumuskan.

\section{PEMBAHASAN}

Desa Dayun ini berada di tempat yang tropis. Untuk lebih mendalami bagaimana bentuk kerjasama bagi hasil perkebunan kelapa sawit yang dilaksanakan oleh masyarakat Desa Dayun, peneliti melakukan kunjungan wawancara kepada beberapa responden untuk memahami lebih mendalam mengenai pelaksanaan bagi hasil yang dirasakan masyarakat dalam tinjauan fiqih muamalah terhadap dampak bagi hasil yang mereka laksanakan. Responden yang diwawancara secara komprehensif sebanyak 10 Responden yang peneliti pilih yakni 5 petani/pengelola dan 5 pemilik lahan kelapa sawit yang bermukim di Desa Dayun.

Responden dalam penelitian ini adalah masyarakat Desa Dayun baik pengelola kelapa sawit maupun pemilik lahan kelapa sawit yang bermukim di Desa Dayun sebanyak 30 orang terpilih dimasukkan dalam penelitian ini, yaitu : karakteristik responden berdasarkan jenis kelamin, usia, tingkat pendidikan, dan tingkat pendapatan.

Berdasarkan hasil yang didapatkan dijelaskan bahwa mayoritas responden adalah berjenis kelamin laki-laki sebesar $100 \%$, jadi dapat disimpulkan bahwa mayoritas responden dalam penelitian ini adalah laki-laki yang mempunyai tingkat tanggung jawab sebagai kepala rumah tangga sehingga lebih berani dalam pengambilan keputusan dan lebih terbuka. Pada umumnya laki-laki mempunyai tingkat wewenang yang tinggi baik di dalam lingkungan keluarga maupun di lingkungan masyarakat.

Berdasarkan hasil yang didapatkan dilihat bahwa responden yang berusia dibawah 30 tahun berjumlah 10 orang dengan persentase sebesar 40\%, responden yang berusia 31-40 berjumlah 20 orang dengan persentase $60 \%$. Artinya pada tingkat usia 31-40 tahun mempunyai tingkat kematangan pengalaman dan wawasan yang cukup dalam mengambil keputusan dan tindakan.

Berdasarkan hasil yang didapatkan diketahui dari 10 responden diperoleh frekuensi responden berdasarkan tingkat pendidikan, yaitu SMP sebanyak 10 orang dengan persentase 40\%, frekuensi responden tingkat pendidikannya SMA adalah sebanyak 20 orang dengan persentase $60 \%$. Artinya mayoritas masyarakat di Desa Dayun memiliki latar belakang pendidikan yang cukup tinggi sehingga diharapkan mampu memberikan kinerja yang tinggi sesuai keahlian dan kemampuan yang dimiliki.

Berdasarkan hasil yang diperoleh dapat dijelaskan bahwa tingkat penghasilan responden antara pengelola dan pemilik kelapa sawit mayoritas berpenghasilan di atas Rp 15.000.000 yaitu sebanyak 15 orang dengan persentase $50 \%$ dan di atas Rp. 30.000.000 sebanyak 5 orang dengan persentase $20 \%$. Sedangkan 10 orang hanya berpenghasilan dibawah $\mathrm{Rp}$ 10.000.000 dengan persentase 30\%, dengan tingkat penghasilan seperti ini maka mereka akan mengalami kemudahan financial untuk memenuhi kebutuhan keluarga.

\section{Perjanjian Kerjasama Bagi Hasil Kelapa Sawit di Desa Dayun Siak}

Pelaksanaan kerjasama bagi hasil perkebunan kelapa sawit di Desa Dayun 
adalah bagi hasil berdasarkan kebiasaan masyarakat yang telah terjadi. Adapun kerjasama pembagian hasil yang dilakukan masyarakat Desa Dayun adalah sebagai berikut :

1. $4 / 5$ bagian / sama dengan $80 \%$ (empat perlima untuk pemilik lahan). Pemilik mendapatkan 4/5 (empat perlima) karena pemilik yang memiliki lahan dan pemilik juga yang menyediakan peralatan untuk menggarap kelapa sawit.

2. $1 / 5$ (satu perlima untuk pengelola lahan). Pengelola hanya mendapatkan $1 / 5$ dari hasil kelapa sawit.

Cara pembagian ini dilakukan karena pengelola hanya bertugas untuk memanen kelapa sawit atau sebagai pekerja kelapa sawit. sedangkan pemilik kebun menyediakan lahan dan peralatan serta menanggung peralatan kerusakan alat. Dengan catatan pemilik kebun menanggung semua biaya peralatan dan kerusakannya, dan pengelola/ penggarap sebagai pekerjanya. Jadi kalau dilihat dari awal perjanjian, kerjasama yang terjadi tidaklah salah, bahkan dari segi pembagian keuntungan juga adil dan sah.

Jika terjadi kerusakan alat yang disebabkan oleh pemilik maka pengelola tidak ikut bertanggung jawab menanggung beban kerusakan. Namun, jika terjadi kerusakan alat yang disebabkan oleh pengelola maka pengelola bertanggung jawab atas kerusakan barang tersebut dengan dipotongnya keuntungan bagi pengelola.

\section{Gambar 1. Skema Bagi Hasil}

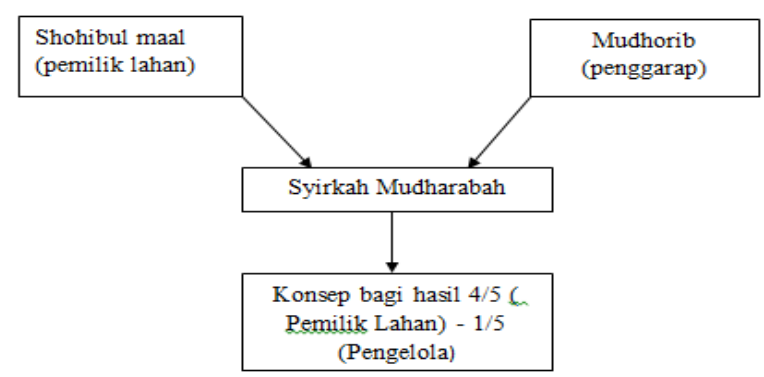

Pelaksanaan bagi hasil di Desa Dayun berdasarkan dari kebiasaan masyarakat dan adat masyarakat tersebut secara turun temurun yang telah berlangsung sejak lama. Namun pada hakekatnya perjanjian bagi hasil ini pada umumnya yaitu pemilik lahan ingin mengproduktifkan lahannya tanpa ia mengerjakan sendiri. Sedangkan pengelola lahan adalah mengelola dan mengerjakan lahan sampai bener-bener mendapatkan hasil dari lahan sawit.

Dari hasil analisa penulis di lapangan, adapun bentuk perjanjian yang mereka sepakati terdiri pada dua bentuk kesepakatan, yaitu: Pertama, seperlima dari hasil panen untuk pengelola atau pekerja dan satu lagi catatan peralatan dan kerusakan alat ditanggung oleh pemilik kebun. Kedua, separoh dari hasil panen untuk pengelola atau pekerja dan separuh lagi untuk pemilik kebun atau lahan dengan catatan peralatan dan kerusakan Alat ditanggung oleh pengelola/pekerja.

Apabila dilihat dari kedua bentuk perjanjian di atas, kerjasama yang terjadi tidaklah salah, bahkan juga dari segi pembagian keuntungan juga sudah adil dan sah, hanya saja akad kerjasama tersebut tidak tertuangkan dalam bentuk sebuah perjanjian tertulis yaitu perjanjian di mulut saja atau hanya secara lisan, sehingga akad perjanjian tersebut mempunyai kelemahan dari segi kekuatan hukum. 
Menurut hasil wawancara penulis dengan pengelola/pekerja, pembagian dari keuntungan dihitung pada setiap akhir bulan, pada pembagian keuntungan inilah salah satu responden bahwa salah satu bentuk kerjasama bagi hasil antara pemilik lahan melakukan sistem musaqah yang mana pemilik lahan menyerahkan sebidang tanah untuk diurus dirawat untuk menghasilkan buah dan penggarap lahan menyediakan waktu dan tenaga dan hasilnya dibagi dari hasil yang disepakati bersama

Dari hasil wawancara yang dilakukan oleh pemilik lahan dan penggarap mereka melakukan sebagian masyarakat ada menggunakan sistem muzara'ah yang mana penggarap hanya melakukan penanaman dari bibit benih yang diberikan oleh pemilik lahan untuk ditanami, disirami dan dipupuk hingga menghasilkan buah dan modal dari sipemilik lahan.

Berdasarkan uraian di atas bahwa konsep bagi hasil di Desa Dayun dalam aspek hukum Islam masuk kategori sah, karena sistem bagi hasil yang dilakukan walaupun secara lisan tetapi sudah sesuai akad. Sistem bagi hasil ini bisa dikatakan bentuk syirkah mudharabah karena kedua belah pihak mendapat keuntungan dari hasil panen kelapa sawit dan sesuai dengan akad perjanjian yang disepakati bersama.

Tabel 1.

Aspek Bagi Hasil

\begin{tabular}{|c|c|c|}
\hline Pemilik lahan & $\begin{array}{l}\text { Pemilik dana memberikan seluruh } \\
\text { modal untuk dikelola }\end{array}$ & $\begin{array}{lrr}\text { Kedua } & \text { belah } & \text { pihak } \\
\text { melakukan } & \text { kesepakatan }\end{array}$ \\
\hline Pengelola lahan & $\begin{array}{l}\text { Pengelola memeberikan seluruh } \\
\text { tenaga dan waktu untuk } \\
\text { menggarap lahan kelapa sawit }\end{array}$ & $\begin{array}{l}\text { kerjasama antara pemilik } \\
\text { lahan dan penggarap untuk } \\
\text { melakukan sistem bagi yang } \\
\text { telah disepakati bersama } \\
\text { diawal perjanjian secara } \\
\text { lisan/ ucapan }\end{array}$ \\
\hline
\end{tabular}

Tabel 2.

Aspek dari Segi Akad

\begin{tabular}{|c|c|c|c|}
\hline Akad & Definisi & $\begin{array}{c}\text { Praktek } \\
\text { dilapangan }\end{array}$ & Hasil \\
\hline Ijab & $\begin{array}{l}\text { Ijab dan qabul harus jelas } \\
\text { menunjukkan hasil kedua belah } \\
\text { pihak antara ijab dan qabul harus } \\
\text { bersesusain (Selaras) antara ijab } \\
\text { dan qabul harus bersambungan }\end{array}$ & Pemilik lahan & Memilih \\
\hline Qabul & $\begin{array}{l}\text { Suatu pernyataan menerima dari } \\
\text { pihak kedua atas penawaran yang } \\
\text { dilakukan oleh pihak pertama }\end{array}$ & $\begin{array}{l}\text { Pengelola lahan/ } \\
\text { pekerja }\end{array}$ & Memilih \\
\hline
\end{tabular}


Tabel 3.

Aspek dari si Aqidain

\begin{tabular}{ll}
\hline Al- Aqidain & $\begin{array}{l}\text { (Subjek) para pihak yang berakad sebagai sesuatu perbuatan hukum } \\
\text { yang mengemban hak dan kewajiban }\end{array}$ \\
\hline Pemilik lahan & $\bullet \quad$ Harus aqil yaitu orang yang harus berakal sehat \\
Dan & $\bullet$ Tamyuz yaitu orang yang dapat membedakan baik dan buruk,. \\
Pengelola lahan & $\bullet \quad$ Muktar yaitu orang yang bebas dari paksaan.
\end{tabular}

Gambar 2.

Skema Bagi Hasil

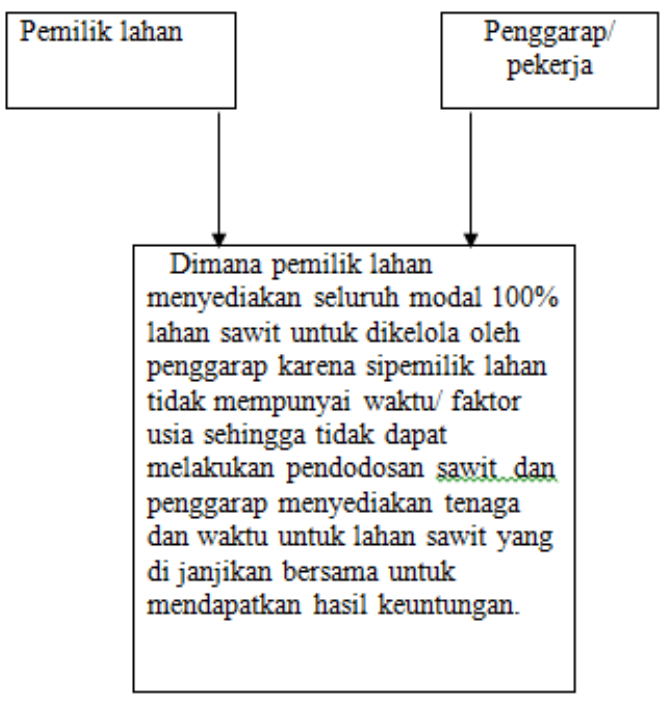

Jadi, berdasarkan 4 aspek bagi hasil, aspek dari segi akad, aspek dari segi aqidain dan aspek syirkah mudharbah bisa dilihat bahwa ada pemilik modal yang menyediakan seluruh modal nya 100\% untuk dikelola oleh penggarap untuk mendapatkan hasil yang yang diinginkan diantara kedua bela pihak dimana ada kesepakatan di awal perjanjian antara pemilik lahan dan pengelola secara ucapan/ lisan.

\section{SIMPULAN}

Dari uraian yang telah dikemukakan dapat disimpulkan sebagai berikut:

Bentuk sistem perjanjian bagi hasil adalah pertama, seperlima dari hasil panen untuk pengelola atau pekerja dan empat perlima lagi untuk pemilik kebun atau pemilik lahan yang bertindak sebagai pemodal, dengan catatan peralatan dan kerusakan alat ditanggung oleh pemilik kebun.

Jika terjadi kerusakan alat yang disebabkan oleh pemilik maka pengelola tidak ikut bertanggung jawab menanggung beban kerusakan. Namun, jika terjadi kerusakan alat yang disebabkan oleh pengelola maka pengelola bertanggung jawab atas kerusakan barang tersebut dengan dipotongnya keuntungan bagi pengelola.

Sebenarnya perjanjian yang dilaksanakan oleh penggelola dan penggarap kalau dianalogikan dalam kajian Fiqih Muamalah hal tersebut dinamakan Syirkah Mudharabah. Namun penggarap dan pemilik serta pihak yang terkait belum mengenal istilah Syirkah Mudharabah. 


\section{DAFTAR RUJUKAN}

Abdurahman, bin Al-Bassam Abdullah. (2006). Syariah Baluqul Maram. Jakarta : Pustaka.

Arikunto. S. (2010). Prosedur Penelitian: Suatu Pendekatan Praktik (Edisi Revisi). Jakarta : Rineka Cipta.

Hakim, Lukman. (2012). Prinsip- Prinsip Ekonomi Islam. Jakarta : Erlangga.

Leksono, Sonny. (2013). Penelitian kualitatif Ilmu Ekonomi. Jakarta : Rajawali Pers.

Sugiyono. (2009). Metode Penelitian Kualitatif dan $R$ dan d. cet.G. Bandung : CV. Alfabeta. 